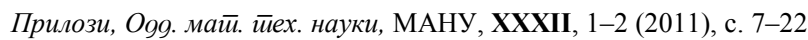
Contributions, Sec. Math. Tech. Sci., MANU, XXXII, 1-2 (2011), p. 7-22

ISSN 0351-3246

UDC: $620.97: 551.556]: 621.31(497.7)$

\title{
EFFECTS OF WIND FARM OPERATING REGIMES IN THE POWER SYSTEM OF MACEDONIA
}

\author{
Anton Čauševski, Tome Boševski
}

$\mathrm{A} \mathrm{b} \mathrm{s} \mathrm{t} \mathrm{r}$ a $\mathrm{c} \mathrm{t}$ : The trend for achieving sustainable energy development, keeping the environment clean and utilization of renewable energy sources are imperative to the energy development in several countries. Through legislation and economical benefits, countries tend to encourage potential investors for building the technologies for energy production from renewable. In order to achieve the EU energy target to have $20 \%$ renewable in 2020 , the technologies for producing electricity from renewable energy sources (RES) are used to cover the needs with more intensities. The most dominant renewable is the wind power plants (WPP) or wind parks, which are used to supply electricity to more power systems (EPS) and whose installed capacity in some European countries reaches thousands MW. This paper treats the issue of operational work of wind power in the power system of Macedonia. It is made of simulation work with wind power plants with total installed capacity of $150 \mathrm{MW}$ with an annual production of $300 \mathrm{GWh}$. The considered power system of Macedonia is projected for the period of 2015 with an annual consumption of $10,000 \mathrm{GWh}$. The power plants considering operating in the simulated period are the existing thermal power units and hydro power plants together with the planned gas power plants and hydro power plants. The aim of this paper is to analyze the effects of the power system operation in case to have installed wind power plants, or what operation mode of thermal power plants (TPP) and hydro power plants (HPP) is most convenient when the system has a source of technology from the renewable with stochastically nature. This is especially important, because conventional power plants (TPP and HPP) operate and regulate the needs of consumption in the power system, but the wind power plants operate when the wind occurs within certain limits of 
technical operating mode for wind turbines. Although wind is free renewable energy source, frequency of occurrence of wind with unpredictable nature and stochastically, has additional adverse impact in terms of power system operating mode. Certainly the impact of wind power on the overall the power system operation depends on power plants and configuration of the power system. In other words, the base load is covered from TPP fossil fuel or nuclear plants, and the dynamic nature of wind power can be incorporated in the power system depends on how much power plants for peak load are available in the system (storage reversible hydro or gas turbines), or how variable power can be accepted in the power system.

Key words: renewable, wind, power, thermal, hydro, storage

\section{WIND ENERGY POTENTIAL IN MACEDONIA}

According to the investigations for potential locations of wind power in Macedonia only certain sites are suitable for construction of such technologies for utilizing the wind energy. Macedonia, according to geographical location as a landlocked country with a predominantly mountain-valley configuration, and of course taking into account meteorological conditions, is most suitable wind turbines to be installed in relatively inaccessible areas that require additional investments in infrastructure. According to the studies of possible sites for wind farms, technically feasible and economically to deliver the energy are wind parks with installed capacity of around $50 \mathrm{MW}$ and a capacity factor of about $23 \%$. Based on these studies and projects concerning the wind power in Macedonia, the paper illustrates the simulations of the Macedonian power system operation with wind power plants with total installed power of $150 \mathrm{MW}$ and annual production of $300 \mathrm{GWh}$. The installed power of $150 \mathrm{MW}$ in wind farms is around $10 \%$ of total installed power today in Macedonia, which is acceptable for power system operation.

\section{MODELLING THE OPERATION OF WIND FARMS IN POWER SYSTEM}

The main feature of the renewable, especially wind energy, is the unpredictable nature and stochastically of the wind. The wind blowing is a result of air masses streams, and its intensity depends on many natural, climatic and meteorological conditions, so the wind has strongly expressed stochastic nature. Therefore, in order to have and recognitze some "security" of the occurrence 
and intensity of the winds, it is required to take multi-measurements in the potential sites for the wind farms.

In the model for power system operation, which consists of power plants on fossil fuels (coal, oil and gas), hydro (storage, reversible, or run of river) and wind power plants, electricity consumption is considered in chronological form, which is especially important for renewable with stochastic nature. The model consists of finding the optimal mode of thermal and hydro power plants operation in a case when the wind power and energy are injected with certain intensity which depends on wind occurrences.

Let the number of contracted power plants which operate in power system consists of:

- $k$ - thermal power plant contracts, each engaged with the power of $P_{\text {ter }}(t)$

- $m$ - hydro hydropower plants, each with power engaged $P_{\text {hyd }}(t)$

- $\mathrm{n}$ - additional systems or interconnections with the power of engaged $P_{\text {sys }}(\mathrm{t})$

- $w$ - number of wind farms, each engaged with power $P_{\mathrm{wpp}}(t)$.

Optimal mode of power system operation consists of finding the minimum integral costs of the entire power system throughout the period, according to the relation:

$$
\sum_{k=1}^{K} \sum_{t=1}^{T} K_{k}\left(P_{\text {ter }}(t)\right) \cdot \Delta t+\sum_{n=1}^{N} \sum_{t=1}^{T} K_{n}\left(P_{\text {sys }}(t)\right) \cdot \Delta t \Rightarrow \min
$$

Where, $K_{k}$ expreses the cost characteristics of TPP contract, and $K_{n}$ expreses the cost characteristics of the additional systems or interconnections. These cost characteristics are presented with a 3 degree polynomial.

Also the model includes the conditions for the balance sheet as follows:

- Power balance between generation and consumption in each time interval according to the relation:

$$
\sum_{k} P_{\text {ter }}(t)+\sum_{m} P_{\text {hyd }}(t)+\sum_{n} P_{\text {sys }}(t)=P_{\text {consume }}(t)-\sum_{v} P_{\mathrm{wpp}}(t)
$$

- Water balance in storage hydro power plants $\left(m_{a}\right)$, taking into account the storage capacity and the water inflows for each subinterval $T_{m j}$ : 


$$
\sum_{m=1}^{m_{a}} \sum_{T m j=1}^{T m v} \mu_{m j} \cdot\left(V_{m, T m j}^{\text {discharge }}-V_{m, T m j}^{\text {inf low }}\right)
$$

- Power balance for each TPP contract during the whole period:

$$
\sum_{k=1}^{K} \rho_{k} \cdot\left|\sum_{t=1}^{T} P_{\text {ter }}(t) \cdot \Delta t-W_{k}\right|
$$

The powers from wind farm and from the load are on the right side of relation (2). The wind power has unpredictable and stochastic nature, whereas the electricity consumption $\left(P_{\text {consume }}(t)\right)$ has seasonal variation (wintersummer) or in respect of (day-night) variations. Power of wind farms $\left(P_{v p p}(t)\right)$ in each interval is taken based on the wind measurements in some locations in Macedonia, which does not mean that it happens in each year or every interval.

The model and application is implemented with the software package developed by the authors. The optimization procedure respects the balancing power and energy in each time interval, balancing power under contracts with TPP, and balancing of water resources in the HPP.

\section{INPUT DATA FOR THE POWER SYSTEM OF MACEDONIA}

The power system of Macedonia has been taken as an example of analysis of the impact of power system operation in case of wind power plants. According to the investigation of wind power in Macedonia, the first wind farm can realistically be built in 2015. Therefore, the simulations are made of the power system for the period 2015-2020, which consists of the existing lignite TPP: TPP Bitola and 1, 2, 3 Oslomej, the oil fired TPP Negotino, and the new gas TPP: TE-TO Skopje, Kogel and the Energetika ELEM. The hydro power system is taken with all existing HPP parameters after revitalization, including the storage Lukovo pole, HPP Sv Petka and HPP Boskov most. The annual consumption is $10,000 \mathrm{GWh}$ represented by chronological hourly loads (8760). The wind power is represented with a wind farm with installed capacity of $150 \mathrm{MW}$ and annual generation of $300 \mathrm{GWh}$. Table1, and Table 2 give the basic data for TPP and HPP in the power system of Macedonia. 
Table 1

Basic data for TPP

\begin{tabular}{lcccl}
\hline \hline TEC & $\begin{array}{c}\text { Pnet, } \min \\
(\mathrm{MW})\end{array}$ & $\begin{array}{c}\text { Pnet, } \max \\
(\mathrm{MW})\end{array}$ & $\begin{array}{c}\text { Annual generation } \\
\text { W }(\mathrm{GWh})\end{array}$ & Fuel \\
\hline Bitola & $3 \times 129=387$ & $3 \times 209=627$ & $3 \times 1450=4350$ & Lignite \\
Oslomej & 73 & 109 & 650 & Lignite \\
Negotino 1 boiler/2 boiler & $65 / 129$ & $100 / 198$ & 1000 & Oil \\
TE-TO Skopje & 139 & 230 & 1600 & Natural gas \\
Kogel * & 0 & 30 & 150 & Natural gas \\
Energetika ELEM & 20 & 30 & 160 & Natural gas \\
Total & $\mathbf{6 8 4} / \mathbf{7 4 8}$ & $\mathbf{1 1 2 6} / \mathbf{1 2 2 4}$ & $\mathbf{7 9 1 0}$ & \\
\hline \hline
\end{tabular}

* 10 motors, each of $3 \mathrm{MW}$

Table 2

Basic data for HPP

\begin{tabular}{llccc}
\hline \hline HPP & Basin & $\begin{array}{c}\mathrm{N} \times \mathrm{Q}_{\text {inst(unit }} \\
\left(\mathrm{m}^{3} / \mathrm{s}\right)\end{array}$ & $\begin{array}{c}\mathrm{Q}_{\text {inflow }} \\
\left(\mathrm{m}^{3} / \mathrm{s}\right)\end{array}$ & $\begin{array}{c}\mathrm{P}_{\text {inst }} \\
(\mathrm{MW})\end{array}$ \\
\hline Vrben* & Mavrovo & $2 \times 4.6$ & 3.75 & 13 \\
Vrutok* & Mavrovo & $4 \times 8$ & 11.81 & 157 \\
Raven* & Mavrovo & $3 \times 10.7$ & 11.81 & 22 \\
Tikves & Crna river & $4 \times 36$ & 27.40 & 116 \\
Boskov Most & Radika & $2 \times 10.5$ & 5.33 & 68 \\
Globocica & Crn Drim & $2 \times 27$ & 28.47 & 42 \\
Spilje & Crn Drim & $3 \times 36$ & 45.16 & 84 \\
Kozjak & Treska & $2 \times 50$ & 21.15 & 82 \\
Sv. Petka & Treska & $2 \times 50$ & 22.53 & 36 \\
Matka & Treska & $2 \times 20$ & 23.91 & 9 \\
Total & & & & $\mathbf{6 2 9}$ \\
\hline \hline
\end{tabular}

* taken into account the inflows from Lukovo pole

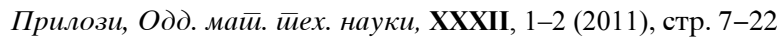


It should be mentioned that the simulations are made taking into account the planned outages for thermal power plants and the water inflows for HPP for the representative of the average hydrological year.

\section{SIMULATION OF THE POWER PLANTS OPERATION IN THE POWER SYSTEM OF MACEDONIA}

Using the software program and input data listed in Tab.1, Tab.2, there are made the simulation of operation of the Macedonian power system without and with wind power in the system. The wind power has a total installed capacity of $150 \mathrm{MW}$ with an annual production of $300 \mathrm{GWh}$ or $3 \%$ of total consumption which is $10000 \mathrm{GWh}$.

In the case of power system operation with wind power plants, it means that we have the additional production of $300 \mathrm{GWh}$ of wind farms, while in the case of power system operation without wind farms, this production is supplemented by the system (electricity imports). In both cases, the electricity generation from TPP and HPP is the same, with the TPP contributed $7970 \mathrm{GWh}$, and the HPP in $1730 \mathrm{GWh}$. This means that the power system should always have an extra reserve of power and energy capacity, which can be enough for operation of the wind power capacities.

In order to analyze the operation of power plants, the following part shows the operation of the TPP and HPP individually for the selected winter and summer week of the year in both cases, with and without wind power in the power system of Macedonia. It should be noted that the selected winter and summer weeks are chosen based on the wind occurrences, having in mind the role of the wind power in the power system.

\section{POWER SYSTEM OPERATION IN THE SELECTED WINTER WEEK}

In order to see the difference between power system operations with and without wind farms, the selected winter week is certainly one of those when there is wind energy in the system. The winter week is a characterized with high consumption and the operation of thermal and hydro power plants with the capacities near installed ones. Figure 1 gives graphically the cover of total consumption with TPP and HPP, as well as the wind power for the selected winter week. 


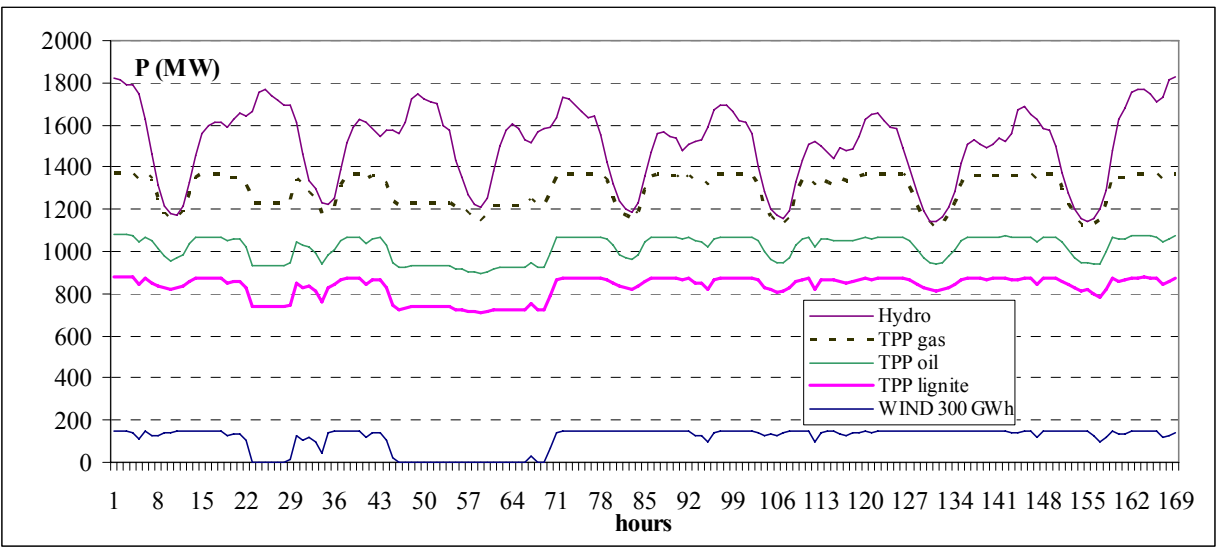

Fig. 1. Covering the demand and the wind power for the selected winter week

The selected winter week has a relatively long occurrence of wind with almost maximum power that is injected into the power system. The wind blows in the night hours of low consumption as well as during the daily hours of high and peak load.

Fig. 2 and Fig. 3 present the hydro power plants operation, and the thermal power plants operation respectively, for the same winter week for both cases, with and without wind power in the system.

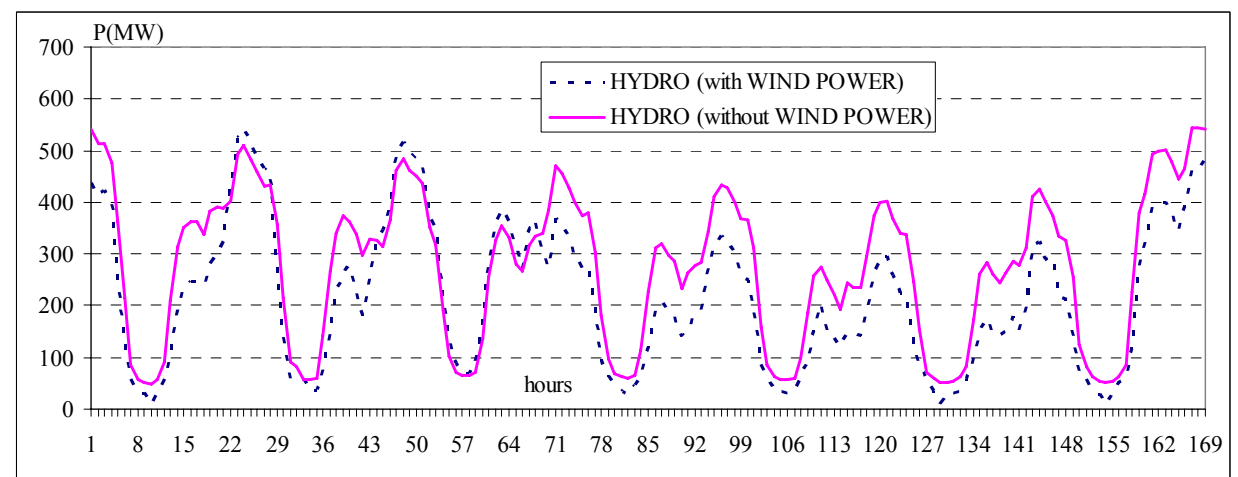

Fig. 2. HPP operation for both cases, with and without wind power for the selected winter week

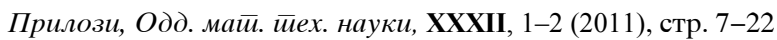




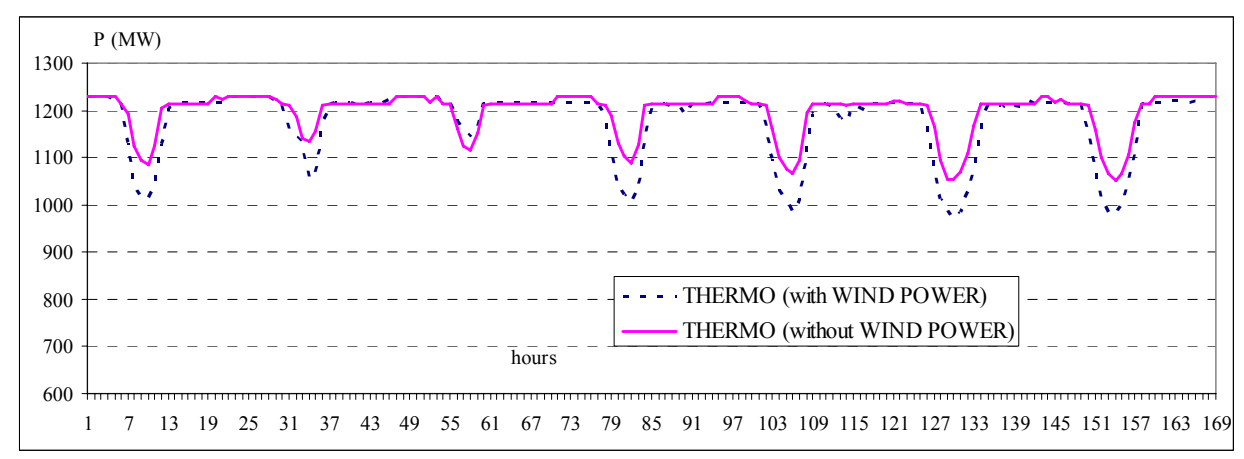

Fig. 3. TPP operation for both cases, with and without wind power for the selected winter week

The simulations show that the part of low demand (during night hours) in the case with wind power, the same one is injected into the system affecting the power reduction in thermal power plants (suppression of TPP). Certainly, the suppression can go to the technical minimum of TPP, while the excess wind power will be injected in the system, and those hydro power plants which operate can certainly reduce the power engagement.

In the part of the high and variable demand (during the daily hours), the wind power affects the power reduction of hydro power plants, which means water saving potential in storage HPP. The storage hydro power plants are the most flexible power plants in the power system, which can respond to the dynamic behaviour of wind power and can react appropriately to power system requirements.

\section{POWER SYSTEM OPERATION IN THE SELECTED SUMMER WEEK}

The selected summer week is characterized with low consumption and is a period when the thermal power plants are out of operation according to the annual planned outages scheduling. Regardless of lower consumption, the occurrences of wind power can bring more variations in the engagement of TPP and HPP in the system. Figure 4 gives the coverage of the total consumption with TPP and HPP, as the well as wind power for the selected summer week. 


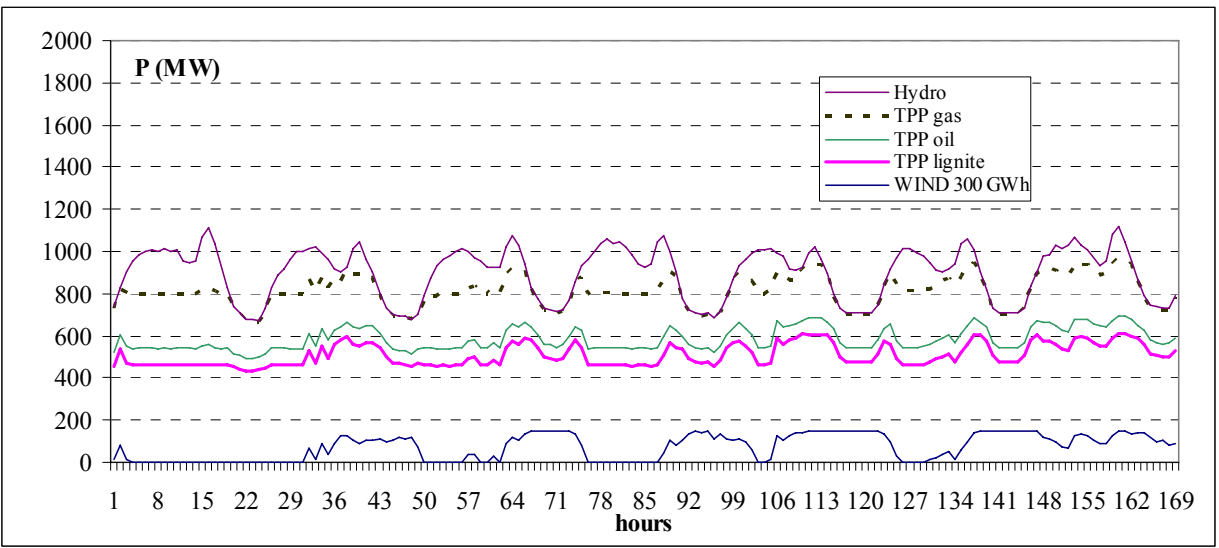

Fig. 4. Demand covering and the wind power for the selected summer week

Fig. 5 and Fig. 6 present the hydro power plants operation and the thermal power plants operation respectively, for the same selected summer week for both cases, with and without wind power in the system.

In the case of a summer week when the thermal power plants operate in low power, reduction at night in case of wind energy can be more then the technical minimum allows (bellow Pnet, min). The additional variable energy can be obtained in daily intervals of high consumption when the storage HPP operates, and can adequately reduce the power depending on wind power.

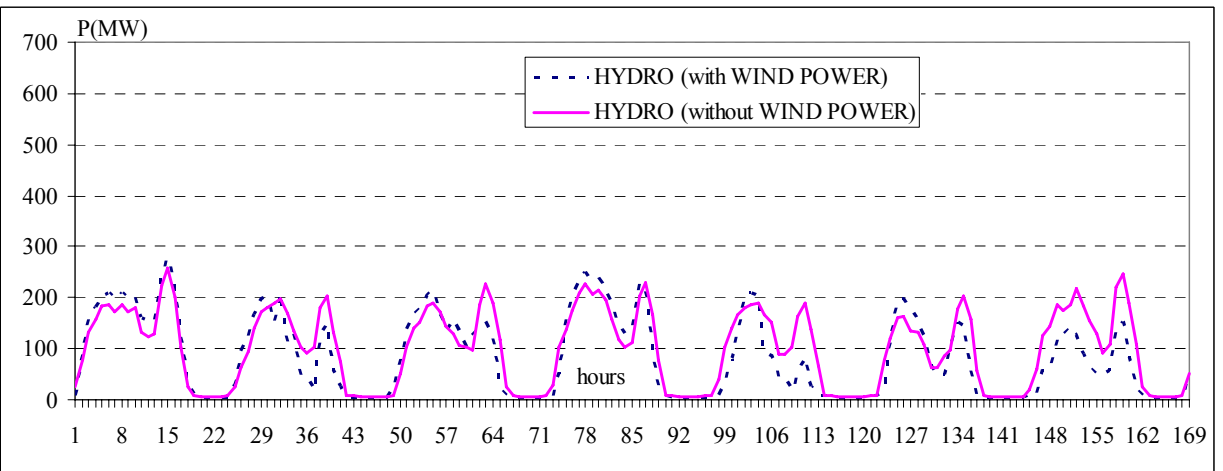

Fig. 5. HPP operation for both cases, with and without wind power for the selected summer week

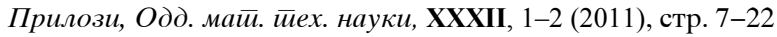




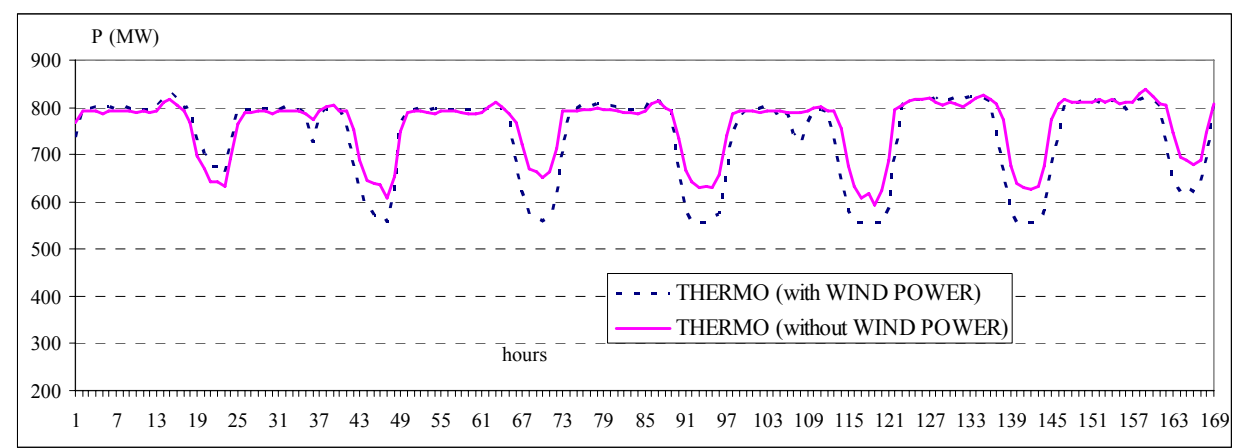

Fig. 6. TPP operation for both cases, with and without wind power for the selected summer week

\section{CHANGES IN OPERATING REGIMES OF POWER PLANTS IN A POWER SYSTEM}

As the part of the integral calculations and simulations, the previous section illustrates the power system operation for the selected winter and summer week in two cases: with and without wind power. Based on the annual operation of power plants, we can obtain the additional variable power and energy in the system as a consequence of wind power occurrences. On the other hand, we can determine the suppressed power and energy in the night hours, which can mean lost energy in thermal power plants.

The additional variable energy in the system as a consequence of the wind power can be obtained in the intervals when the storage HPP or gas fired power plants (CHP or CC) Kogel and TE-TO Skopje are in operation. In that case, they can reduce the power related on power injected from wind farms. These amounts of saved water in storage HPP or gas in gas fired power plants, can be spent and used in other intervals depending on the consumption needs.

Suppressed energy in TPP and the whole power system can be obtained with the relation:

$$
W_{\text {supressed }}=\sum\left(P_{\mathrm{WPP}}(t)-\sum_{\text {variable }} P_{\mathrm{PP}}(t)\right) \cdot \Delta t
$$

$$
\text { But only for the time intervals } \Delta t \text { when } P_{\mathrm{WPP}}(t)>\sum_{\text {variable }} P_{\mathrm{PP}}(t)
$$


Where $\sum_{\text {variable }} P_{\mathrm{PP}}(t)$ is the sum of power for all plants entering the balancing of the variable of consumption (mainly storage HPP or gas power plants). This means that in the intervals when the appearance of wind power $P_{\mathrm{WPP}}(t)$ is higher than the amount of power at all engaged storage HPP and TPP entering the balancing of the variable portion of electricity consumption $\sum_{\text {variable }} P_{\mathrm{PP}}(t)$, the excess wind power $\left(P_{\mathrm{WPP}}(t)-\sum_{\text {variable }} P_{\mathrm{PP}}(t)\right)$ can be accepted or can be suppressed in the TPP or interconnected power systems. The intervals of suppressed energy are mainly in the night hours when the base load power plants (TPP lignite or nuclear) operates on low power because of the small consume.

The compensated additional variable power from the wind power plants is the difference of the total wind energy less then suppressed power in TPP and interconnected power systems, as the following:

$$
W_{\text {var. WPP }}=W_{\mathrm{WPP}}-W_{\text {supressed }}
$$

Depending on which power plants are in variable power balancing, the following 3 cases are taken into consideration for the power system of Macedonia:

- Storage HPP are the power plants for covering the variable load,

$$
W_{\text {supressed }}=\Sigma\left(P_{\mathrm{WPP}}(t)-P_{\text {storageHPP }}(t)\right) \cdot \Delta t
$$

- Storage HPP and Kogel gas power plants are the power plants for covering the variable load,

$$
W_{\text {supressed }}=\sum\left(P_{\mathrm{WPP}}(t)-P_{\text {storageHPP }}(t)-P_{\text {Kogel }}(t)\right) \cdot \Delta t
$$

- Storage HPP, Kogel and TE-TO Skopje gas power plants are the power plants for covering the variable load,

$$
W_{\text {suppressed }}=\Sigma\left(P_{\mathrm{WPP}}(t)-P_{\text {storageHPP }}(t)-P_{\text {Kogel }}(t)-P_{\text {TE-TOSkopje }}(t)\right) \cdot \Delta t
$$

The total annual wind energy in the system is $W_{W P P}=300 \mathrm{GWh}$. According to the simulations, the obtained results for the suppressed energy in TPP and the additional variable energy are the followings: 
- Storage HPP are the power plants for covering the variable load, $W_{\text {supressed }}=123,3 \mathrm{GWh}(41 \%$,$) and W_{\text {var.WPP }}=176.7 \mathrm{GWh}$ or around $59 \%$.

- Storage HPP and Kogel gas power plants are the power plants for covering the variable load,

$W_{\text {supressed }}=114.8 \mathrm{GWh}(38 \%$,$) and W_{\text {var_WPP }}=185.2 \mathrm{GWh}$ or around $62 \%$.

- Storage HPP, Kogel and TE-TO Skopje gas power plants are the power plants for covering the variable load,

$$
W_{\text {supressed }}=17.6 \mathrm{GWh}(4 \%,) \text { and } W_{\text {var.WPP }}=282.4 \mathrm{GWh} \text { or around } 96 \% \text {. }
$$

Figure 7 gives the graphical presentation of the suppressed energy and additional variable energy in the power system which depend on regulating power plants for variable demand.

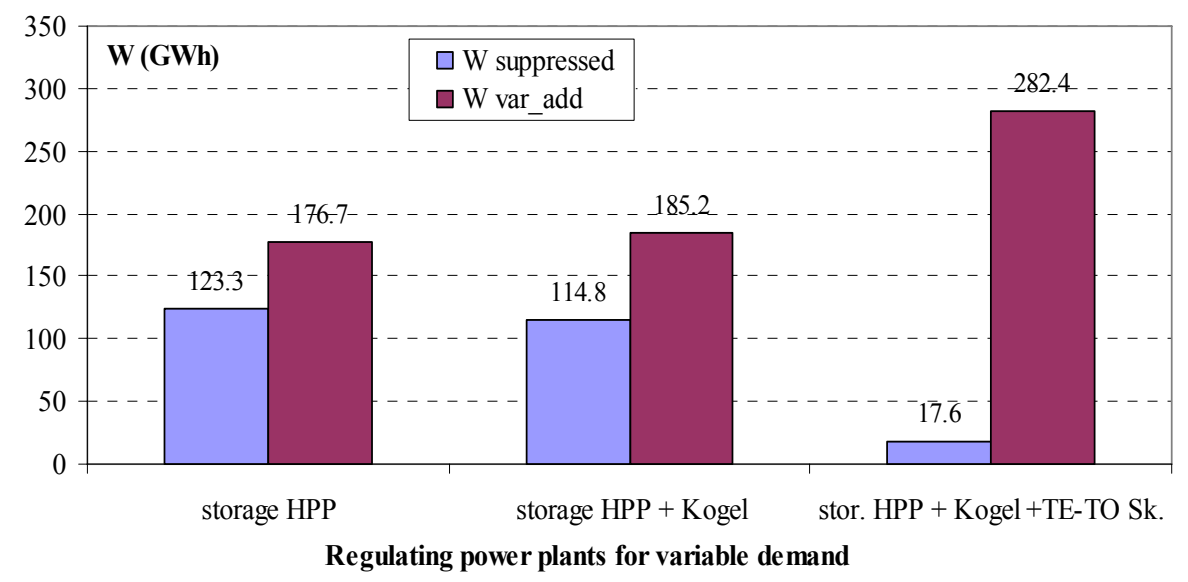

Fig. 7. Suppressed energy and additional variable energy in the power system which depends on regulating power plants for variable demand

In the cases when Kogel and TE-TO Skopje, both gas power plants, participate as regulation power plants for covering the variable part, their role in having additional variable energy as the consequence of wind power in the power system is presented in Fig. 7. 


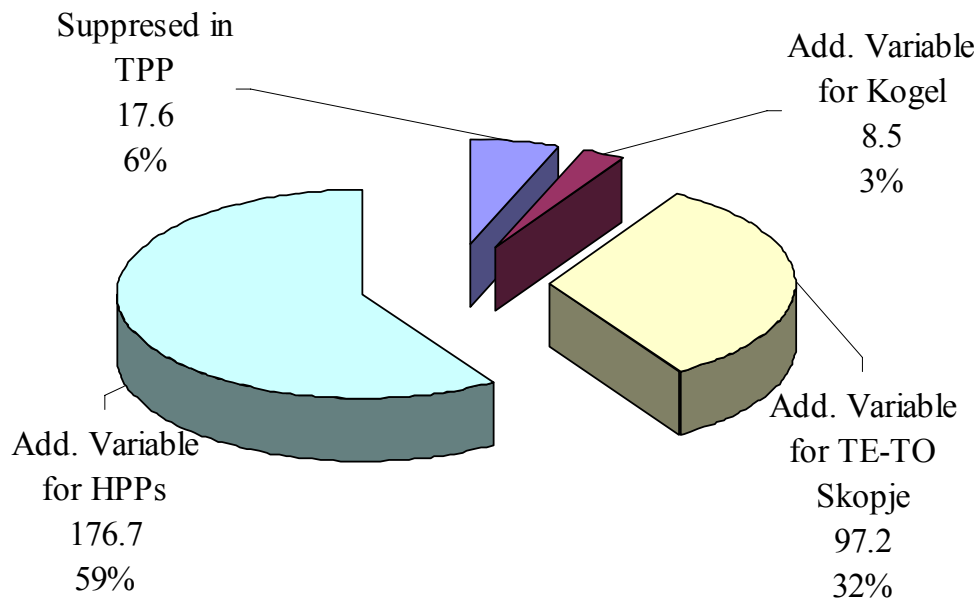

Fig. 8. Suppressed energy in TPP and additional variable energy for HPP and gas power plants

The last two figures give the main point of the analysis for power plants operation with wind power. When the number of regulating power plants increase, the accepted variable energy from wind power is also increased and the suppressed power to the base thermal power plants decreased. It means that the additional variable can be accepted from the storage HPP or others regulating power plants (gas fired ones).

\section{CONCLUSION}

Dynamic and especially stochastic nature of the wind power and energy injected into the system with a certain intensity which depends on third power of wind speed, can cause additional disturbances in the power system operation. In order to operate the entire system, it is necessary to have power plants in the system that can accept dynamic mode of wind occurrences. Such power plants can be reversible HPP, storage HPP, or special gas power plants, which should be flexible enough to respond quickly to any change of power and energy injected by the wind farms in the power system.

The operating changes and impacts of the power system from the wind power would be effectively amortized in the case of having storage hydro 
power plant(s) as regulated power plant(s) (with accumulated water) which can appropriate respond to variable needs and to the dynamical behaviours of wind power. If the power system does not have the appropriate storage hydro installed capacity, the dynamics of the system with wind power should be accepted by thermal power units or interconnected systems. It is especially important mode of thermal power plants operation in the hours when storage HPPs are not on grid or the night hours of low demand. In the case of having wind power in these intervals when TPPs already operate on low power, it should be further reduced their power but until to the limit of the technical minimum of the units. Certainly, this reaction of TPP means lost energy (and fuel of course) in thermal power units, because thermal power plants are not designed to work in such dynamical mode. On the other side, this TPP operation mode means faster ageing of the units and, of course higher probability to have more unexpected failures. However, if the need for reduced power in TPP because of wind power emergence the blocks higher, it should be suppressed to the minimum limit, and the excess wind energy should be injected into the system or interconnected power systems should take this power.

The analysis for the operation of the Macedonian power system in case with and without wind power shows that the additional variable energy in the system as a consequence of the wind power is only in the hours of high consumption or in the peak loads in the day. In these intervals, storage HPP can reduce the power output according to the injected power from wind farms. This energy, or saved water in the reservoirs means additional energy savings in storage HPP, that could be spend in other intervals. For the analyzed power system the additional variable energy is around $180 \mathrm{GWh}$ or about $60 \%$ of the total annual wind energy which is $300 \mathrm{GWh}$. The remaining approximately 120 GWh or about $40 \%$ can be saved in other regulated power plants in the system, or otherwise can be suppressed in the thermal power plants or in interconnected systems. In the case when gas power plants as Kogel and TE-TO Skopje participate in power regulation to cover the variable part of consumption, then the variable substituted energy in Kogel is $8,5 \mathrm{GWh}$ or about $3 \%$, while the TE-TO Skopje is $97 \mathrm{GWh}$ or about $32 \%$, which remains suppressed energy in other TPPs is $18 \mathrm{GWh}$, or about $6 \%$

Finally, it should be noted that this analysis is based on the current and future projected situations of our power system with water inflows for average hydrology. The ratio between the suppressed energy and additional variable energy in the system can change, depending on the configuration of regulated power plants that can accept the variable energy in the power system and, of course, depending on hydrology as available water in hydro power plants. 


\section{LITERATURE}

[1] Anton Čauševski, Tome Boševski; Improved model for electricity generation planning in the small economic autonomous power system, ETRAN 2003, Herceg Novi, 8-13 June 2003, Zbornik radova, Sveska I.

[2] Technical reports from ELEM and MEPSO.

[3] WYG International; Wind Park Development Project Macedonia, Feasibility Study Bogdanci A, 2010.

Р ез и м е

ЕФЕКТИ ОД РАБОТА НА ВЕТЕРНИ ФАРМИ ВО ЕЕС НА МАКЕДОНИЈА

Трендот за постигнување на одржлив енергетски развој, зачувување на чиста животна средина и користење на обновливи извори на енергија се императив за енергетскиот развој. Преку законска регулатива и економски бенефиции, земјите имаат тенденција да ги охрабрат потенцијалните инвеститори за изградба на технологии за производство на енергија од обновливи извори. Со цел да се постигне енергетската цел на ЕУ, технологиите за производство на електрична енергија од обновливи извори на енергија (ОИЕ) сѐ помасовно се користат за покривање на потребите. Најмногу доминираат ветерни електрични централи (ВЕЦ) или ветерни паркови, кои се користат за снабдување на електрична енергија во повеќе електроенергетски системи (EEC) и чии инсталирани капацитети во некои европски земји достигнуваат илјадници мегавати.

Овој труд го третира прашањето на оперативната работа на ветерните електрани во EЕC на Македонија. Направена е симулација на работата на ветерни електрани со вкупна инсталирана моќност од $150 \mathrm{MW}$ и годишно производство од $300 \mathrm{GWh}$. Симулацијата е направена на проектирана состојба на ЕEC на Македонија за 2015 година со годишен конзум од $10.000 \mathrm{GWh}$. Производниот систем работи со постојните термоцентрали и хидроцентрали заедно со планираните гасни електрани и хидроелектрични централи кои треба да се изградат до 2015 година.

Целта на овој труд е да се анализираат ефектите на работата на интегриран ЕEС составен од термоцентрали (ТЕЦ) и хидроцентрали (ХЕЦ) со ветерни електрани (ВЕЦ) како извори на технологија од обновлива стохастична природа. Стохастичната природа на појава на ветрот и соодветната инјектирана моќност и енергија во ЕЕС може да се компензира доколку во ЕЕС има повеќе извори кои можат да прифатат варијабилна промена на конзумот како акумулациони ХЕЦ, реверзибилни ХЕЦ или пак други термоенергетски постројки кои се подготвени за варијабилна работа во ЕЕС (гасно турбински електрани).

Електрани кои можат да го покријат варијабилниот дел од конзумот со денешната изграденост на ЕЕС во Македонија се само акумулационите ХЕЦ. Меѓутоа, појавата на ветрот е со далеку подинамична промена во однос на варијабилноста на конзумот. Варија- 
билноста и динамичноста на конзумот сепак има некоја очекуваност и предвидлива форма во однос на сезоната (зима-лето) или во однос на едно деноноќие од 24 часа (ден-ноќ). Всушност, динамиката на конзумот е основна причина за тарифирањето во текот на деноноќието, односно висока тарифа во часовите на висок конзум и активност, како и ниска тарифа во ноќните часови на појава на низок конзум во ЕEC.

Можноста за прифаќање на ветерни електрани во ЕЕС зависи од способноста на хидроелектраните (акумулациони и реверзибилни) кои можат да ја прифатат динамиката на промена на моќност и енергија, како од конзумот така и од технологиите на ОИЕ.

Клучни зборови: обновливи извори на енергија, ветерна енергија, термо, хидро, акумулација

Adress:

\section{Anton Čauševski}

Ss. Cyril and Methodius University in Skopje

Faculty of Electrical Engineering and Information Technologies

Rugjer Boshkovik bb

PO Box 574, MK-1001 Skopje

Republic of Macedonia

caus@feit.ukim.edu.mk

Tome Boševski

Macedonian Academy of Sciences and Arts

Bul. Krste Misirkov, 2, P.O. Box 428

1000 Skopje, Republic of Macedonia

bosevski@feit.ukim.edu.mk 